of the Phlegræan Fields, drawn up by Mr. Günther, was presented. Mr. Giinther's work being still in progress, the report $w$ ts of a preliminary nature, but it is satisfactory to note that the materials for the investigation have proved more valuable and abundant than was anticipated.

On Tuesday morning Mr. W. N. Shaw, F.R.S., exhibited a complete series of the weather maps published daily by various countries. Most of these bore the date January I, I90I ; others June I, I90I. The list is interesting as showing the position of this branch of meteorology at the beginning of the twentieth century :-Austria, Bavaria, Belgium, British Isles, Denmark, France, Germany, Holland, Italy, Portugal, Russia, Saxmy, Spain, Switzerland, Algeria, Australasia, Canada, India, Bay of Bengal, Japan, Mexico, United States, Roumania.

The rest of the morning was devoted to papers on the Antarctic expeditions. Dr. J. Scntt Keltie described the organisation and equipment of the National Antarctic Expedition, and Dr. H. R. Mill gave an account of the voyage of the Discovery as far as Madeira, to which point he accompanied the vessel for the purpose of working out the details of the meteorological and oceanographical routine. Mr. W. S. Bruce then read a paper on the methods and plans of the Scottish National Antarctic Expedition, in which he announced that sufficient funds had been subscribed, entirely by Scotsmen, for one complete year's work in the Antarctic. It is proposed to purchase a whaler of about five hundred tons, and to leave this country in about a year's time. The ship will carry a scientific staff of five, five officers, and a crew of twenty. An attempt will be made to push as far south as possible in the Weddel Sea, and the deep reported by Ross in lat. $68^{\circ} \mathrm{S}$., long. $13^{\circ} \mathrm{W}$., will be specially investigated. The expedition will confine itself almost entirely to marine work, and it is not intended to winter in the ice.

In the afternoon Mr. H. Yule Oldham read a paper on the experimental demonstration of the curvature of the earth's surface. Mr. Yule Oldham has repeated Wallace's Bedford level experiment on the old Bedford River between Welney Bridge and Denver Bridge, a perfectly straight stretch of six miles. A mark was set up midway botween the bridges, at the same height above water level as marks on the two bridges, and found to stand six feet above the line of sight. Records of the experiment have been obtained by the use of a special telephotographic lens.

Dr. R. Logan Jack then gave an account of an expedition in Western China, in which the Chengtu Plain was crossed five times, and a good deal of mapping done of the margins of the plain, and the courses of the rivers reaching it from the north. At the Maha gold mines the party received information of the massacres at Pekin, and were advised to make for Burma. Bhamo, in Upper Burma, was reached after many difficulties.

A paper, by Mr. Archibald Little, on the Crux of the Upper Yang-tse, was read by Mrs. Little. The paper contained an extremely graphic account of, an ascent of the river during the flood season, and the condition of the country and of river navigation was compared with that obtaining during the winter.

The last paper was by M. Galeron, designer of the great celestial globe at the Paris Exhibition, on the representation of the heavens in the teaching of cosmography. After pointing out the difficulty experienced by the student in realising the apparent positions and motions of the heavenly bodies from a study of the ordinary celestial globe, in which the celestial sphere was represented as seen from the " outside," M. Galeron exhibited and described an apparatus in which a celestial globe is made of thin muslin, and sufficiently large for the head of the observer to be placed at the centre. The apparatus, which can be constructed very simply and cheaply, enables the chief phenomena to be demonstrated with great clearness.

It is roteworthy that the Artisan's Lecture this year, although geographical, was not an account of travel and exploration, but an exposition of the application of geographical principles. In his lecture on "The Movements of Men by Land and Sea," Mr. Mackinder showed how the progress of civilisation has been affected by the configuration of the Earth's surface, and pointed out the profound changes going on in political and social life under our eyes, as the result of the development of the great ocean lines of communication and of the transcontinental railways. The lecture was a perfect illustration of the aims and methods of the " new geography," and should do much to make those better understood and appreciated.

NO. I 667, VOL. 64]

\section{EDUCATIONAL SCIENCE AT THE BRITISH} ASSOCIATION.

THOUGH the new Section of the British Association was only appointed for $a^{\circ}$ year, the success of the moetings at Glasgow was of so decided a character that the Section will probably become a permanent part of the Association. It can scarcely be said at present that an educational science exists, but the statement of methods and results, and the discussion of the relationships between principles and practice, apart from all political considerations, should do something to organise the conclusions of people who have given serious attention to educational problems. The Section will exert the greatest influence in connection with scientific studies; and there is no reason why it should not lead to improvements in method's of teaching as valuable as those which have been produced by the scheme for a course of work in chemistry, drawn up by Dr. H. E. Armstrong for the British Association Committee on the methods of teaching chemistry. It is not too much to say that this scheme started a revolution which gathers strength every day. The system of science instruction by didactic methods still exists in places, but only because the machinery for carrying on the work on more rational principles has not been obtained. Wherever the object is education, the nsethods of research have been introduced, and it is recognisęd that real scientific knowledge can only be gained by individual experience.

\section{Educational Experiment and Research.}

Sir John Gorst accepted the principle of research in education in his address as president of the Section, and Dr. Armstrong emphasised it in an early paper. The power of research, the art of acquiring information for oneself, must, he pointed out, be cultivated in all because it is the power on which advance in life depends. The chief work of the Section will be to teach this doctrine, and impress it upon the teachers. A science of education must be shaped, and a national programme must be constructed in which research methods are encouraged and teachers are trained to have sympathy with them. The human. ists must enter into an alliance with the naturalists, and the union should take place on equal terms. At present our educational system is entirely one-sided. The schools still at best suffer science; they do not love it and the old universities do not even regard it as a necessary element of culture.

Reform will be brought about by the development of workshop and laboratory methods. The experimental method of teaching is adapted to the curiosity and activity of the average boy, and should be the basis of instruction at the earliest stages. Prof. L. C. Miall gave strong support to the experimental method, which he described as the most complete embodiment of the methodised art of trying, of ignoring failures and im. proving successes, and perpetually going on until the goal was reached. This is the habit it is desired to set up and which will take an important place in future educational work. Sir Michael Foster emphasised the view that science is not learnt in the lecture room, but in the laboratory. The first aim should be to teach a boy to think, and this can be done by practical work properiy arranged. It has been stated over and over again that pupils who have been prepared by the older learning take to science more readily when they are brought to it than those who have been trained from the very beginnings in science. This, Sir Michael said, was easy to understand, because teachers in the humanities have been trained to teach for generations, while men of science are only now beginning to learn how to teach.

Methods of teaching are of great importance, and the British Association can be the means of producing improvements in them. Prof. H. L. Withers, however, in a paper on the scope of educational science, expressed the opinion that before deciding how this or that subject should be taught it is desirable to formulate a theory of the curriculum, that is, to arrive at some conclusion as to the proportional value of subjects. Mr. P. A. Barnett also took this view, the main argument of his paper being that the criterion of success in education must be, not what people have been taught to do or to make, but what they are and how they bear themselves in all the relationships of life. But the educational value of a subject even considered from this point of view depends upon the scope of the subject and the methods of teaching, so that a reasonable curriculum cannot be drawn up until a decision has been arrived at as to what is implied by the name of each subject. 
As instances of differences of opinion as to what should be included in a sulject and how the suliject should be taught, the discussions on the teaching of elementary mathematics and of botany may be cited. In each case a whole morning was devoted to the expression of expert opinion and the statement of experience in relation to the subject under discussion. For the discussion of the former subject, a joint meeting was arranged with the mathematical depirtment of Section A, and for the latter a joint meeting was held with the Section of Botany.

\section{The Teaching of Mathematics.}

In urging a reform of mathematical teaching, Prof. Perry remarked that he would teach mithematics - at all events advanced mathematics -in different ways to different students. In any case he thought the system of teaching boys elementary mathematics as if they were all going to be pure mathematicians must be altered. We taught all boys what is called mathematical philosophy that we might catch in our net the one demigod, the pure mathematician, and we did our best to ruin all the others. In his experience there was scarcely any man who might not become an advancer of knowledge, and the earlier the age at which you gave him the chances of exercising his individuality the better. Educate through the experience already possessed by a boy; look at things from his point of view-that is, lead him to educate himself. Through his whole mathematical course let him be taught through his own experiments, and do not call it waste of time to plot the stream lines, for example, after the algebraic academic answer of a problem has been arrived at. The unpractical nature of mathematical teaching, he held, caused men to leave common sense out of their teaching, and he instanced the great continental Polytechnics, where an elaborate course of many months, or a year, was often devoted to a subject, of which the general principles could be grasped in a practical course of a few weeks.

All advocates of orthodox methods seemed willing to sacrifice every form of usefulness of mathematics to the mind-training inherent in a perfect logical system-a huge complex deduced logically from simple fundamental truths. Where would be the harm in letting a boy accept the truth of many propositions of the first four books of Euclid, partly by faith, partly by trial; of giving him the whole fifth book by simple algebra; and in letting him assume the sixth book as axiomatic? He would allow him, in fact, to begin his severer studies where he was now in the habit of leaving off; and would let him put aside much more than is usually done, so that he would get quickly to the solution of partial differential equations and other useful parts of mathematics. He had been speaking of the training of the mathematician, and he might be wrong; but as to the educational training of the man who was to use his mathematics in the study of pure and applied physical science, he had no doubt whatever of the importance of skipping judiciously in all early mathematic work. In these days all men ought to study natural science, and in such study they required to have the knowledge of algebraic formulæ and the power to use them ; to be familiar with the use of logarithms in computation; with the use of squared paper, and with the methods of the calculus. He held that dexterity in these is learned by quite young boys, and he felt sure that such dexterity could not hinder, and could only further, the mathematical study of the exceptionally clever student.

Mathematics was a powerful weapon to unlock the mysteries of Nature. If a man knew how to use the method, that would be enough; he could leave to others, who delight in that, the forging and complete study of the weapon. The average young engineer might be made to possess a power of using the methods of mathematics, which would be as easy to him as reading or writing or using any hand tool-a power which would never grow rusty, because it would be exercised every day of his life ; and his present hatred of mathematics and theory of engineering was leading to disaster. Higher mathematics had become a very useful thing. As in the case of all other generally useful things, the complete study of its philosophy in the orthodox manner was not a necessary part of the school or college curriculum. In concluding his remarks, Prof. Perry defended himself against the charge which his engineering friends had brought against him, that he had an exaggerated notion of the importance to all men of possessing a love for mathematics.

The discussion upon the paper was commenced by Prof. Hudson. He said that a too common fault in teaching mathe-

NO. I667, vOL. 64$]$ matics consisted in allowing the pupil to learn by heart pro. positions, formulæ and rules, instead of using them as a means of training the ressoning powers. He trusted that Prof. Perry did not really wish to recommend that method, but he was afraid that its advocates might quote Prof. Perry in their support. Elementary teaching should be so conducted as to prepare for more advanced teaching; nothing should have to be unlearnt. Geometry should be based on the observation and handling of models of solid figures, and thus could be begun at a much earlier age than was generally supposed. Prof. Forsyth criticised the vehemence of the attack which Prof. Perry had made upon the mathematician while sympathising to a considerable extent with his aims. He pointed out that subjects do not necessarily progress on the lines of direct usefulness, and that very many of the applications of the theories of pure mathematics had come many years-sometimes centuries - after the discoveries themselves; the weapon had lain ready to hand, but the man had not been there to use it. He also indicated briefly his views on the teaching of elementary mathe. matics, and advocated the inclusion of a course on practical geometry early in the pupil's career. With this suggestion, that the pupil should be led to pure geometry only after he had been accustomed to handle and to work with the figures with which geometry is concerned, all the subsequent speakers cordially agreed. Prof. Forsyth further desired to point out the need of a proper system of training teachers so that when they began their profession they would not have to devote their time to practising upon their earliest pupils the method that happened to suit their own particular temperament. Major MacMahon-the president of Section A-joined in the discussion, but confined his remarks to the subject of elementary teaching without entering upon the more important questions raised by the address, which he had already dealt with in his opening address to the Section. Prof. Riicker said that there seemed to be a general agreement among all the speakers that, in the case at all events of the younger children, the teacher ought to approach the subject as far as possible from the concrete side. He also held, with Prof. Perry, that a somewhat rapid advance was advisable in the first case, the various qualifications with which the general statements had to be guarded being entered upon later. While not attacking the system of examinations-which had come in for severe criticism by other speakers-he considered that it had its weak points, but that it was a necessary part of our educational apparatus. Prof. Silvanus Thonıpson and Prof. Henrici were in entire accord with Prof. Perry; and the latter expressed the hope that qualified mathematicians would prepare text-books upon the lines laid down in the address. Prof. Everett pointed out the need of distinguishing between technical and liberal education, and Prof. Miall criticised the system in which the needs of the pupil and teacher were sacrificed to the demands of the examiner and inspector. Mrs. W. N. Shaw spoke upon the bearing of the discussion on the education of girls; and there also joined in the debate, Mr. J. Parker Smith, M.P., Prof. Greenhill, Prof. Alfred Lodge, Prof. Minchin, Mr. E. M. Langley, and others.

An immediate result of Prof. Perry's address has been the appointment of an influential committee of the Association, with Prof. Forsyth as president and Prof. Perry as secretary, to report upon improvements that might be effected in the teaching of mathematics.

\section{The Teaching of Botany.}

The joint discussion on the teaching of botany was held in the rooms of Section K, Prof. Bayley Balfour being in the chair. Mr. Harold Wager introduced the discussion by reading a paper on the teaching of botany in schools. He said that more attention should be paid to methods of teaching if the subject was to take its proper place in the school curriculum as a part of the general scientific training. Too much time should not be spent in mere descriptive work; and the use of the compound microscope should not be encouraged. The right selection of topics was important. Such subjects as experimental plant physiology, the structure and germination of seeds, and the structure and function of the flower were specially to be commended. A good grip of fundamental principles and not an imperfect acquaintance with a vast number of facts was wanted in school teaching.

Prof. Bower read a paper on the teaching of botany in universities. $\mathrm{He}$ also urged that the use of the microscope in schools should not be allowed. It should be left to the university course. Thoroughness in special branches should be 
aimed at with advanced students, not encyclopædic knowledge. Method was far more important than mere information. Advanced students should be left to work independently as much as possible. Research should be encouraged, but futile investigations were a mistake. Stress should be laid upon writing up the results of any piece of work in good literary form.

In the subsequent discussion, Prof. Miall said that in his elementary teaching at the Yorkshire College the laboratory work was the most important part of the work. Lectures were not given, but after a period in the laboratory a discussion on the facts observed took place in the lecture room, and the students were expected themselves to give an account of their work. They very soon learnt to express themselves clearly and easily, and had little difficulty in passing examinations. Prof. Marshall Ward agreed that observations formed a very important part of elementary botany, and children could be taught to reason from facts observed. With advanced students research was a powerful stimulus in developing interest in the subject. Prof. Withers believed that the study of science might well begin with natural history. Chemistry and physics should then be taken, and such a subject as botany might again be taken up in the higher forms. But as a training in scientific method he thought the value of botany was often extremely small.

Prof. Armstrong considered that more, attention might be given to systematic botany, and science altogether should be taken more seriously in schools, and at least half the school time should be given to practical work. Chemistry and physics, as well as botany, were required in order to give the student a good knowledge of scientific method. Dr. D. H. Scott said that there was often too much specialisation in the syllabuses drawn up for elementary classes. His experience as an examiner had shown him that the subject could be easily crammed without developing any real knowledge of the subject. Dr. Kimmins gave the opinion, as the result of his experience, that botany was often very badly taught in schools because of the want of properly trained teachers. He thought it was a pity that there was a tendency to replace it altogether by physics and chemistry.

Sir John Gorst said that it seemed to him that one of the best science subjects for purposes of general education was botany, especially for rural schools. The provision of laboratories and apparatus was a difficulty. Perhaps the County Councils might help with these. Properly trained teachers were required, and the subject should have attention in Training Colleges. Too many rural teachers at the present time were not properly qualified to give simple lessons in botany.

The chairman in closing the discussion said that it had been of great interest, and he felt that improvement would take place as soon as a good supply of properly trained teachers could be obtained.

\section{Organisation and Administration.}

The other subjects dealt with in the Section belong more to the organisation and administrative side of education than to the aims, scope and methods of science teaching, so a brief mention of them will be sufficient in these columns. Sir Henry Roscoe introduced the subject of the organisation of technical and secondary education, and in commenting upon it Sir Michael Foster said that whatever legislation was brought forward it was to be hoped that no distinction would be made between primary and secondary education. Sir Philip Magnus spoke in favour of the unification of educational effort by the creation of local authorities to be responsible for education in their areas. A paper by the Bishop of Hereford on the influence of the universities and examining bodies upon the work of schools contained a plea for the recognition of science and modern languages as substitutes for Greek in Responsions. It was pointed out that the existing requirement of Greek from every candidate desiring to enter the older universities, together with the accompanying exclusion of modern languages and science, practically dissociates the whole class of modern schools or modern departments in schools from direct university influence, and the effect is found to be specially unfortunate in the modern departments of the large secondary schools. The paper will be printed in full by the Association. Among other subjects discussed were commercial education, and the mechanism of education in Scotland. Dr. J. H. Gladstone also read his annual report on the teaching of science in elementary schools, hitherto presented to the chemistry section, but there were few other papers, the system adopted in the arrangement of the programme being to accept only one or two papers for each meeting, and these to be on definite topics requiring dis- cussion. By this means attention was concentrated upon particular aspects of educational work instead of being directed this way and that by a variety of papers. The system has worked so successfully that it will probably be followed at future meetings of the Section.

\section{FORTHCOMING BOOKS OF SCIENCE.}

Mr. Félix Alcan (Paris) gives notice of:- "Les maladies de l'orientation et de l'équilibre," by Prof. J. Grasset ; " Manuel d'Histologie pathologique," by Profs. V. Cornil and L. Ranvier, illustrated, tome second.

Among Mr. Edward Arnold's forthcoming books are :-_" The Balancing of Engines," by Prof. W. E Dalby, illustrated; "A Handbook on Fermentation and the Fermentation Industries," by Charles G. Matthews, illustrated; "Human Embryology and Morphology," by Dr. A. Keith, illustrated; "A Text-Book of Zoology," by G. P. Mudge, illustrated.

Messrs. George Bell and Sons give notice of :- " Elementary Science," by D. E. Jones and Dr. D. S. Macnair ; "Inorganic Chemistry," by Prof. James Walker, F.R.S. ; " $\Lambda$ n Introduction to the Comparative Anatomy of Animals," by Dr. G. C. Bourne, vol. ii. :-The Coelomata; "Elementary Differential Calculus," by Prof. A. Lodge, with an introduction by Prof. Oliver J. Lodge, F.R.S. ; "An Elementary Treatise on Cubic and Quartic Curves," by A. B. Basset, F.R.S.

Messrs. A. and C. Black promise :- "A Treatise on Elementary Statics" (for the use of schools and colleges), by W. J. Dobbs; "New Descriptive Geographies: Africa, Central and South America, North America," edited by Dr. A. J. Herbertson and F. D. Herbertson.

Messrs. Blackie and Son, Ltd., will issue :- " The World of Animal Life, an Introduction to the Wonders of the Animal World," illustrated.

In the list of the Cambridge University Press we notice:"Fables and Folk Tales from an Eastern Forest," collected and translated by Walter Skeat, illustrated; "Mathematical and Physical Papers," by Sir G, G. Stokes, F.R.S., vol. iii. "Scientific Papers," by Lord Rayleigh, F.R.S., vol. iii. It is expected that the work will be completed in four volumes. "The Electrical Properties of Gases," by Prof. J. J. Thomson, F.R.S.; "Electric Waves," being an Adams Prize Essay in the University of Cambridge, by H. M. Macdonald; "A Treatise on Determinants," by R. F. Scott. A new edition by (x. B. Mathews, F.R.S.; "The Algebra of Invariants," by J. H. Grace and A. Young; "A Primer of Botany," by F. F. Blackman; "Zoological Results based on material from New Britain, New Guinea, Loyalty Islands and elsewhere, collected during the years 1895, 1896 and 1897," by Dr. Arthur Willey. The entire work will be completed with the publication of part vi., which will be issued during 190I, and will contain Dr. Willey's monograph on Nautilus and other articles, including an account of the Ascidians by Prof. W. A. Herdman, F.R.S. "Reports of the Anthropological Expedition to Torres Straits by the Members of the Expedition," edited by Prof. A. C. Haddon, F.R.S., vol. ii. :-Physiology and Psychology. It is expected that the work will be completed in five volumes. "Biometrika. A Journal for the Statistical Study of Biological Problems," part i.; " The Fauna and Geography of the Maldive and Laccadive Archipelagoes," being the account of the work carried on and of the collections made by an expedition during the years 1899 and 1900 under the leadership of J. Stanley Gardiner, part i. of vol. i.; "Index Nominum Animalium," compiled by C. Davies Sherborn under the supervision of a committee appointed by the British Association and with the support of the British Association, the Royal Society and the Zoological Society, vol. i. .(1758-1800); "Fossil Plants," a manual for students of botany and geology, by A. C. Seward, F.R.S., vol. ii.; "Electricity and Magnetism," by Dr. R. T. Glazebrook, F.R.S., "Hegelian Cosmology," by J. McT. E. McTaggart ; "Essays on Educational Subjects," by Prof. S. S. Laurie.

Messrs. Cassell and Co., Ltd., will publish :- "The Earth's Beginning," by Sir R. S. Ball, F.R.S., illustrated ; and new editions of :- " Tumours, Innocent and Malignant, their Clinical Characters and Appropriate Treatment," by J. Bland Sutton, illustrated; "Surgical Applied Anatomy," by Sir Frederick Treves, K.C.V.O., assisted by Dr. Arthur Keith, illustrated. 